\title{
Professional transitions towards sustainable farming systems: The development of farmers' professional worlds
}

\author{
Xavier Coquil $^{\mathrm{a}, *}$, Benoît Dedieu ${ }^{\mathrm{b}}$ and Pascal Béguin ${ }^{\mathrm{c}}$ \\ a INRA, UR055 ASTER-Mirecourt, 662 avenue Louis Buffet, F-88500 Mirecourt, France \\ ${ }^{\mathrm{b}}$ INRA, UR1218 dpt SAD, F-63122 Saint-Genes-Champanelle, France \\ ${ }^{\mathrm{c}}$ Institute for Work Studies, UMR 5600-LabEX IMU, University of Lyon, France
}

Received 20 August 2015

Accepted 21 September 2016

\begin{abstract}
.
BACKGROUND: While farming in France and generally in Europe is continuing to intensify, at the expense of its environmental sustainability, promising alternatives are emerging.

OBJECTIVE: The processes whereby farmers change and transform their own work, to shift from an intensive mode of production to a self-sufficient and autonomous one, need to be formalized if we are to further our understanding of why and how these forms of sustainable farming activity emerge.

METHODS: We use the development of professional worlds theory, a systemic representation of workers' activity, whereby their experience is formalized. This can be explained as the praxis ${ }^{1}$, conceptual and axiological underpinnings form a system with the object of the action. The development of a professional world is analyzed according to the evolution of its components and the search for pragmatic coherence within it. We analyzed professional transitions towards self-sufficient and autonomous mixed farming through a case study.

RESULTS: Our findings showed that the transition is initiated by the discovery of the unthinkable, awareness of a discrepancy between what the farmers think and what they do, the appearance of problems, and the response to external constraints. Professional transition is a non-teleological and non-incremental process; it corresponds to a comparison with reality, and a resolution of difficulties. This process is stimulated by the use of artifacts instrumented by the farmers.

CONCLUSION: New perspectives are opened up by this formalization of transitions, in terms of $(i)$ support towards sustainable farming and (ii) the design of sustainable farming systems.
\end{abstract}

Keywords: Professional transition, design, self-sufficiency, autonomy, mixed farming

\footnotetext{
*Address for correspondence: Xavier Coquil, INRA UR 055 ASTER-Mirecourt, 662 avenue Louis Buffet, F-88500 Mirecourt, France. Tel.: +33 0473624294; E-mail: Xavier.Coquil@inra.fr.

${ }^{1}$ Praxis refers to the overall coordination functions and adapt core voluntary movements in order to accomplish a given task.
}

\section{Introduction}

To increase the yields of factors of production (labor, land, animals, etc.), French agriculture makes intensive use of polluting inputs (fertilizers, pesticides), which is proving to be unsustainable from an environmental perspective [1-4]. It also practices specialization (monoculture, intensive indoor 
production $^{2}$ ), which encourages the development of specific diseases and parasites. This intensification and specialization trend is coupled with the automation of farming [5], designed to further increase farmed surfaces and the number of animals per worker. The rationale underpinning this trend, which seeks to put the natural environment at the service of a quantitative production objective, can be summarized as investing to increase productivity at work, and thereby produce large quantities to generate turnover in order to pay off loans and capital and derive income.

Promising alternatives nevertheless exist. This is particularly the case of "self-sufficient and autonomous mixed farming" systems. These farming systems are said to be "self-sufficient" as they seek to eliminate the use of highly polluting inputs [chemical fertilizers, pesticides, allopathic products for veterinary care, feed or feed supplements for animals), and to work almost exclusively with resources produced on the farm. They are "autonomous" insofar as they offer farmers a form of decision-making autonomy allowing them to create a space to share specific know-how between peers. Three dimensions seem to be strategic [6] for farmers implementing these self-sufficient and autonomous systems:

$\square$ The first dimension is technical. Farmers must identify and manage the possible interactions between livestock farming and crop farming on their farm. The economy of these farming systems relies on "metabolic" interactions: the crops are used as feed for the animals, while animal manure is used as fertilizer for the soil. But functional interactions between livestock and crops can also exist. For example, grazing can be used to curb the growth of certain weeds on farm land. These interactions, described by Coquil et al. [6], entail a profound shift in farmers' representation of their farm. Land considered as infertile in an intensive framework

\footnotetext{
${ }^{2}$ Monoculture consists in cultivating the same annual plant on a plot every year, with the aim of maximizing profitability. This monoculture encourages the appearance of weeds, diseases and pests (e.g. insects, European water voles, etc.) specific to that crop. Conversely, annual crop rotations on a plot and the diversification of crops in the landscape are effective means of preventing diseases, pests and the appearance of certain weeds. Intensive indoor production consists of raising a high concentration of animals in air-conditioned buildings (e.g. pigs, poultry, cows, etc.) to control the raising conditions and raise the animals using plant products, mostly imported. This cloistered and high density life increases the speed of dissemination when a disease emerges.
}

may, for example, prove to be highly valuable in the context of an "autonomous" mode of production.

$\square$ The second dimension relates to the need for a profound transformation of farmers' activity. The use of inputs is primarily designed to modify the properties of life forms (animal or crop growth) and of resources (land or food quality) so as to achieve very high productivity, considered as optimal in an intensive model of production. Self-sufficiency and autonomy, on the contrary, involve the identification of the properties of those life forms and of the resources available on a farm, in order to use them better and to limit or even eliminate the use of inputs. In this context, farmers must tailor their farming practices to their farm's properties (and not transform its properties with fertilizers). Farming activity then relies less on knowledge of supposedly optimal generic laws, than on observation and detailed knowledge of the interaction between animals and plants in the specific and singular environment that is a farm.

$\square$ The last dimension can be qualified as "social". Despite the widely demonstrated positive impacts of autonomous farming systems (on an ecological, economic and social level [7-13]), advocates of the intensive farming model sometimes describe it as "backward" or "subsistence" farming, "incapable of meeting the global food challenge". As a result, farmers wishing to implement "autonomous" farming systems must demonstrate "political autonomy" as understood by Castoriadis [14]. In France, these farmers cannot benefit from the services offered by advisory organizations and bodies, still very largely devoted to intensive farming. Autonomous farmers have thus had to create and support their own institution (called "Réseau Agriculture Durable"), to structure a circle of peers in order to acquire and disseminate the knowledge they need, and to promote alternative farming systems. The challenge is not just cognitive or technical; autonomy requires moving away from the dominant professional norms of intensive agriculture.

One can then understand why "self-sufficient and autonomous mixed farming" systems are still a small minority in the French (and even European) rural landscape. Farmers can potentially encounter a large number of difficulties in shifting from a mode of 
thinking and action geared towards productivity to one which values autonomy [15-17].

We argue that understanding the dynamics of change at play in the farming industry requires serious consideration of the work issues encountered by farmers. First, we believe that the reasons driving farmers to make changes in their farming systems are not fully understood. Moreover, we think that professional transitions, in other words the processes whereby farmers make their own work activity, evolve and transform it, to move from an intensive mode of production to an autonomous one, need to be modeled better.

This article explores this research hypothesis. We first present a notional framework designed to analyze professional transitions. On this basis, and drawing on the analyses of 10 farms that switched from intensive production to self-sufficient and autonomous production, we describe: (i) the reasons driving farmers to switch to autonomous modes of production, and (ii) the dynamics at play during professional transitions. Finally, we discuss the contribution of these analyses to think the support of the development of more environmentally-friendly self-sufficient and autonomous farming, and to agronomic research.

\section{Work transitions studied through the prism of professional worlds}

The transition of sociotechnical systems is an emerging theme that led to the creation of an international research community in 2009 (the Sustainable Transition Research Network), with the aim of studying the dynamics of transition towards greater sustainability in various industries (health, education, transport, housing, etc.). It is not possible here to provide an exhaustive review of this highly dynamic research stream (the reader is referred to [18]). Two points are however worth noting:

- This work, which largely stems from economics and sociology, is primarily concerned with largescale issues: governance and public policy, technical infrastructure, the role of civil society (social movement, companies, etc.), or ways of life and modes of consumption. Although these are valuable approaches, the theories produced pay little attention to the transformations of work.

- Although a few rare studies have considered the transformations of professional practices, particularly in the farming industry [19, 20], they look at work from the perspective of its potential or actual effects on sustainability, for example, to determine the relevance of professional practices in terms of their performance, both agronomic (crop or livestock productivity) and environmental (e.g. nitrogen release in water).

This is obviously an important dimension, but it follows an "extrinsic" approach, studying the effects of work and not necessarily the difficulties encountered by work in action, when a professional transition is underway. We argue that an "intrinsic" approach also needs to be developed, that is, one that seeks to grasp how workers relate to the reality with which they are faced, their aims, the means they mobilize to reach them, and the problems they encounter in their work (and that potentially cause them to modify it $)^{3}$.

To this end, we applied the concept of "professional world" [22] to our analysis of professional transitions. An important idea underpinning this concept is that reality is always far too broad and complex to be grasped fully. For a worker, being effective means focusing only on certain dimensions of reality that then become what needs to be understood and acted upon. Bucciarelli [23] for example showed the importance of grasping the same reality in different ways, in an analysis of design activities. What a safety engineer calls "an emergency stop button", an electrical engineer will refer to as a "junction box". For the same reality, the work object (which Bucciarelli calls an "object-world") therefore appears differently to each protagonist, and will be associated with distinct concepts and specific actions, mobilizing different instruments, which refer to particular value systems. Our hypothesis is that professional transitions involve a change of "professional world". Thus, in the move from intensive agriculture to autonomous agriculture, farmers have to focus on other dimensions of the same reality (their farm), mobilize new knowledge, implement new practices, and articulate new professional values.

\footnotetext{
${ }^{3}$ The term "extrinsic approaches" refers to reality perceived from a point of view other than that of the subject(s) involved in the action. For a discussion on the distinction between an intrinsic and extrinsic approach, see [21] Rabardel P, Béguin P. Instrument Mediated Activity: from Subject Development to Anthropocentric Design. Theorical Issues In Ergonomics Science. 2005;6(5): 429-61.
} 


\subsection{The professional world as a prism to analyze transitions}

A professional world can be defined as a relatively stable framework of thought and action, comprised of a set of conceptual elements (what is known), axiological elements (what is valued), and praxis (what is done), that form a system with the object of the action. Each of the entities comprising a professional world can therefore be understood as a prism to analyze transition, insofar as it evolves. According to the model, there are four such entities: the work object (or "object of the activity"), the instruments, the concepts and indicators mobilized, and the values.

The notion of work object is a key concept in historical-cultural approaches to activity [24]. One of the core ideas of these theories is that activity has a purpose. From the outset, the concept of activity and that of the object of activity are closely intertwined and even inseparable: an activity is "object-related" or "object-oriented". The work object can therefore be defined as what an individual retains of the reality of a situation, and on which they act or which they transform to reach a goal. However, in activity theory the word "object" does not denote objective, material reality in general ("the things that exist"). It refers to the idea of the status acquired by things when they are articulated in the activities of a worker interacting with the world. Thus, for example, the object of air traffic controllers' work is pairs of airplanes (and not just airplanes' flying altitude or trajectories).

In activity theories, the concept of the object of activity refers to the rationale underpinning the various behaviors of individuals or groups, and the idea closely relates to "the sense-maker," which provides activities with a purpose and outcome [25]. From that point of view, identifying the object of activity and its change over time can afford a deeper and more structured understanding of professional transitions.

To analyze the instruments mobilized by farmers during transitions, we draw on the theoretical framework of Instrument Mediated Activity [26, 27]. The theory of Instrument Mediated Activity defines an instrument as a 'coupling' between a technical resource and the use to which it is put. For example, a monkey wrench is not an instrument per se; it is only a technical resource, a tool or an artifact. Depending on the use to which it is put, it can serve as a wrench or a hammer. Another simple example is a chair: it can be used to sit on but also to stand on so that one can change a lightbulb. An instrument is therefore a compound entity: it always consists of a tool or artifact—which can be either material (e.g. a chair) or cognitive (e.g. a procedure, a graph) — and of a way of doing things, a human dimension related to how the tool is used and for which purpose. It is this association between the tool and the human dimension that constitutes the instrument (for a detailed conceptual discussion, see in particular Rabardel and Béguin [21]). In accordance with this theory, the analysis of transitions can benefit from identifying the new artifacts used by farmers. But because an instrument is a 'coupling', the analysis cannot be reduced to identifying artifacts only. It is also necessary to examine the use to which they are put: what are the farmers trying to do with the new artifacts, how do they use them and for which purpose?

To analyze conceptualizations, we draw on the work carried out within professional didactics [28]. A central idea in this approach, inspired by the genetic epistemology proposed by Piaget, is that no action can consist merely in implementing existing knowledge. Every action reconstructs the knowledge it needs. This means that during professional transitions, farmers have to produce new conceptualizations in action. One of the challenges for analysis is then identifying the conceptual evolutions informing how a farmer conceives of and defines their work situation, and which reflects professional transitions. Moreover, to act effectively, farmers must select what is truly relevant in the situation. Yet experts identify very little information on the situation. Very often they focus on a detail (or at least on what seems like a detail to the layperson), but are actually going straight to the core. In this sense, the evolution of the indicators picked up by farmers, which seem relevant for action, also constitutes valuable indexes. These indexes attest to the professional transition and help to point to the relevant variables actually taken into account in their work.

Finally, in what a worker does, there are things they value, as opposed to what they do (via instruments) and what they know (via concepts). This axiological dimension (values) is prevalent among farmers in the context of professional transition towards more sustainable forms of agriculture. In the framework of our study, and in keeping with rural sociology [29-32], it seemed useful to distinguish between "values", on the one hand, and "professional norms", on the other. Values position the farmer as a citizen taking part in societal debates, while "professional norms" are constructed through professional debates between 
peers sharing certain values, and which fulfill a social function insofar as norms reflect or even facilitate membership of a professional group or collective. Evolutions of professional norms are an important indicator of professional transition. Values appear as highly stable elements that encompass professional norms (the scope of which is more restricted as it is subject to concrete situations and the evolution of the experience). Nevertheless, developments in the hierarchy of each individual's value system are possible [33], based on cultural, societal and even personal changes, and are worth analyzing in the framework of professional transitions.

\subsection{Professional transition and systemic reorganization of the professional world}

As noted above, a professional world is a system. This raises questions regarding the coherence and systemic compatibility between the elements that comprise it. These ideas of coherence and systemic compatibility suggest that a significant qualitative change in any element of a professional world will potentially generate incompatibilities and contradictions with the other elements comprising it. These internal contradictions constitute a powerful driver of professional transition when they can only be overcome by producing changes in the other elements that make up the professional world. An entity is thus reconstituted: potentially incoherent elements are recomposed and reorganized in a new form, leading to a systemic reorganization that is meaningful to the subject. North American pragmatism, especially that of Dewey [34], has continuously discussed this tension between discordance and coherence. When there is discordance there is disorder, ambiguity, confusion, contradiction and difficulty overcoming them. Yet everyone needs to live a coherent and meaningful life (in the pragmatic sense of having purpose) by re-establishing an organization with an internal autonomy for the acting subject. In addition to highlighting a general dynamic of professional transitions, this principle of systemic reorganization internal to the professional world suggests that a significant transformation of one of the elements of the professional world (irrespective of the origin of this transformation) can indeed lead to the reorganization of the whole. For example, the implementation of a new instrument recommended within the group of peers can challenge professional norms and values. Moreover, professional transitions are not cumulative linear or incremental processes. They are rather processes consecutive to discordances, which generate exploratory, trial-and-error processes, led by one or several farmers on one or several farms, with the aim of re-establishing systemic compatibility.

\section{Farmers' transitions towards autonomous mixed farming}

Professional transitions towards self-sufficient and autonomous mixed farming are studied through the diachronic analysis of the evolution of the activity of 20 farmers working on nine commercial farms, and 17 participants in a farm-scale trial within the State experimental facility of the INRA ASTERMirecourt research unit (INRA: Institut National de Recherche Agronomique, ASTER AgroSystème TErritoire Ressources). This study, based on the evolution of the farmers' activity and that of the participants in the trial, from the beginning of their working life until 2010, spanned the period from 2011 to 2014 .

\subsection{Material and methods}

The method consists of a case study: we develop an inductive approach in which we analyze singularities in order to understand general issues and principles [35]. The approach is prospective: we provide a detailed study of a case in its context in order to understand the principles and properties governing the situation. These methods are based on the in-depth study of a small number of cases.

The ten autonomous mixed crop-dairy farms that are self-sufficient with regard to inputs underwent change from their creation up until 2010. The farmers first worked the farms intensively, using synthetic inputs, and then gradually changed their practices to become more autonomous and to use fewer synthetic inputs.

One of these ten farms was an experimental system tested by an INRA ASTER-Mirecourt research unit. An area of 240 ha was converted to organic farming for the purpose of designing two systems requiring very few inputs: a grassland dairy system, and a mixed crop-dairy system. These two systems, set up in 2004, were designed step-by-step. This is an experimental approach based on ongoing improvement, aimed at solving the technical difficulties encountered along the way and reinforcing the systems' autonomy [36]. The system was designed in a collective that practiced conventional farming prior to 2004, and intensive farming in the early 1980 s. 
The nine commercial farms belonged to a sustainable agriculture network called the Réseau Agriculture Durable (RAD), a federation of farmers all wishing to develop autonomous and self-sufficient farms. The farmers on these nine farms initially farmed intensively, with a high consumption of inputs, before entering a period of transition during which they cut back on the use of synthetic inputs.

The ten farms surveyed present a variety of surface areas under cash crops (excluding maize silage) in the EAL (exploitable agricultural land) - between $0 \%$ and $50 \%$ or more - and different agricultural collectives, including couples, individual farmers, and GAEC (Groupement Agricole d'Exploitation en Commun - farmers' interest group) with or without employees.

We collected data to characterize the farmers' work on these ten autonomous mixed crop- dairy farms that were self-sufficient with regard to inputs by 2010 , and to analyze their professional transition from more intensive farming at the outset.

The data were collected through three series of interviews with farmers of the RAD. The first introductory interview used the open interview technique [37]. During this interview the farmers discussed their definition of mixed crop-dairy farming, and the difficulties and key points for the establishment of this system. The second and third interviews were based on the elicitation interview technique [38]: this technique remains as close as possible to the action underway, in order to identify individual actions and their determinants as they take place, and not as an a posteriori analysis. During the second interview we focused on an elicitation of the course of the 2010 agricultural campaign, that is, the last agricultural campaign that had been completed at the time of the interview. The analysis of this interview was designed to formalize the farmers' work on their autonomous and self- sufficient mixed crop-dairy farms in 2010. Based on these ten farms with varying collectives and each with their own organization, 15 formalizations of the activity of the autonomous and self-sufficient mixed crop-dairy farmers emerged. These 15 professional worlds correspond to the activity of individual farmers or groups of farmers. In the third interview we asked the farmers to go over the steps and events in the transition to autonomy and self-sufficiency with regard to inputs, identified via the analysis of the first interview. We then also asked them to consider the emergence of the practices, instruments and indicators that they used in 2010 and that we identified via the formalization of their activity, based on the second interview. The analysis of this third interview focused on the appearance of artifacts during the transition, on their instrumentation (integration into farmers' agricultural practices), and on the agricultural objects that appeared or were transformed during the use of these artifacts, in the farmers' activity during the transition. Data on the INRA ASTER-Mirecourt experimental station were collected through interviews with the farm managers and through collective and then individual interviews with farm technicians. The active participation of one of the authors of this paper in the design process made it possible to complete this dataset. The data were then used to formalize the agricultural activity of this experimental farm's collective in 2010, as well as its development from the beginning of the career of the head of the experimental unit.

This data collection and analysis work produced one monograph per farm, so ten in all, which were used as material for the transversal analysis. This analysis focused on the artifacts used by the farmers during their transition, the objects transformed by the use of these tools during the farmers' activity, and the agricultural practices and professional norms adopted during the transition. The appearance of new objects revealed the adoption of new operational and cognitive approaches by the farmers, which restructured their work.

\subsection{The factors of initiation of professional transitions}

The farmers' professional transitions were initiated by four factors, and most of the time by the conjunction of at least two of the following: (i) access to the unthinkable, (ii) practical difficulties, (iii) awareness of the gap between "doing" and "thinking" and (iv) external constraint.

- Access to the unthinkable refers to the subjectivity of discovery and to access to a new realm of possibilities through a discovery: this is the case, for example, of a farmer from the Maine et Loire department who, during a technical event to which he had been invited by a friend, met the person who had initiated the movement for self-sufficient and autonomous farming in north-western France. This person suggested halving his farm's dairy production to limit the intensification of his production system and to produce more sustainably by feeding his cows with grass instead of maize silage and expensive imported soybean oil meal. This idea, which shocked the farmer at first, opened up new perspectives for him: he discovered that it was possible to live off farming without 
using up his full quota entitlement ${ }^{4}$. This discovery partly lifted the pressure to produce off this farmer. It allowed him to let go of the imperatives of maximizing fodder production on his plots, requiring relatively expensive fertilizers and pesticides, and of maximizing each of his cows' milk production by buying feed to increase their diets. He discovered the self-sufficient farming rationale: maintaining his farm's profitability not by maximizing production but rather by minimizing costs and therefore purchases. This minimization involved cultivating grass, a balanced plant for cows' diet that is fertilized by the nitrogen in air when associated with a legume (through symbiotic fixation). He gradually experimented with increasing the share of grass grazing in his dairy cows' diet.

- Practical difficulties refer to the technical or economic difficulties encountered by farmers, which prompt them to find solutions. A farmer couple from the RAD experienced many health problems in their herd, along with agricultural price fluctuations exposing them to heavy economic losses during their non-autonomous period. As they were about to face substantial deficits, the technicians and accountants around them suggested that they consolidate their financial situation by taking out a third consolidation loan from the bank. Caught in the dead-end of the intensive system, the couple decided not to take out a third loan and to find an alternative allowing them to work by limiting purchases. Through an acquaintance, they discovered a farming system requiring fewer inputs. They then very significantly reduced purchases and gradually discovered self-sufficient and autonomous systems by implementing them on their farm.

- Certain farmers' awareness of the discrepancy between their way of working and the ideas they defended was a factor triggering their professional transition towards self-sufficient and autonomous farming. This awareness always goes hand in hand with the discovery of the unthinkable or the appearance of a practical difficulty in the farmers' work. Take for example a farmer couple now established in Brittany with an autonomous system: the husband used to work on an intensive mixed-farm and the wife worked for a farming support organization promoting intensive systems. While their respective work conflicted with their interest in small and medium-sized environmentally-friendly farms, it was the discovery

\footnotetext{
${ }^{4}$ In accordance with the European dairy market organization, from 1982 to 2015 every producer was attributed an entitlement quota not to be exceeded.
}

of the concept of reverse development or negative growth ${ }^{5}$ and its implementation on farms practicing self-sufficient and autonomous agriculture that made this discrepancy unbearable. They looked for a small farm in Brittany to start a self-sufficient and autonomous mixed-farming dairy activity, to preserve their integrity regarding farming and the simple and minimalist modes of consumption they advocate.

- A collective of experimenters, within the INRA ASTER-Mirecourt experimental facility, was forced to switch to autonomous mixed farming. This change, following a decision by superiors, went hand in hand with the whole collective's discovery of autonomous mixed farming on commercial farms and with the development of a debate on this self-sufficient and autonomous farming's professional norms. The experimenters' collective thus discovered ways of doing and thinking specific to this self-sufficient and autonomous farming. It discovered that this farming did not just consist in doing without fertilizers and pesticides, but also in introducing new practices involving crop rotation, in order to limit the presence of diseases and weeds in the fields, etc. The collective moreover discovered that the aim in this system was not to dominate nature in order to maximize production, but rather to guide nature for production purposes whilst limiting external purchases. This debate was more or less consistent with the values of the different members of the collective. However, the actual implementation of these farming systems on the experimental farm forced the collective to change their practices. These changes led to the professional transition of some of the participants. In 2010 they enjoyed internal coherence in their work, after having established new professional norms. Others had kept their original professional norms that might encourage them to work towards more productive farming, and sometimes caused situations of malaise at work.

\subsection{Professional transition is a non-incremental and non-teleological development}

Once initiated, the transition is a continuous process of resolution of emerging problems, of confronting desires regarding the future with the possibility of fulfilling them, and confronting the virtual

\footnotetext{
${ }^{5}$ Reverse development or negative growth refers to a political, economic and social concept, defending that economic growth is more a source of harm than benefit to humanity. Activists are in favor of an ethic of voluntary simplicity (anti-productivist, anticonsumerist, anti-capitalist).
} 


\section{Professional world}

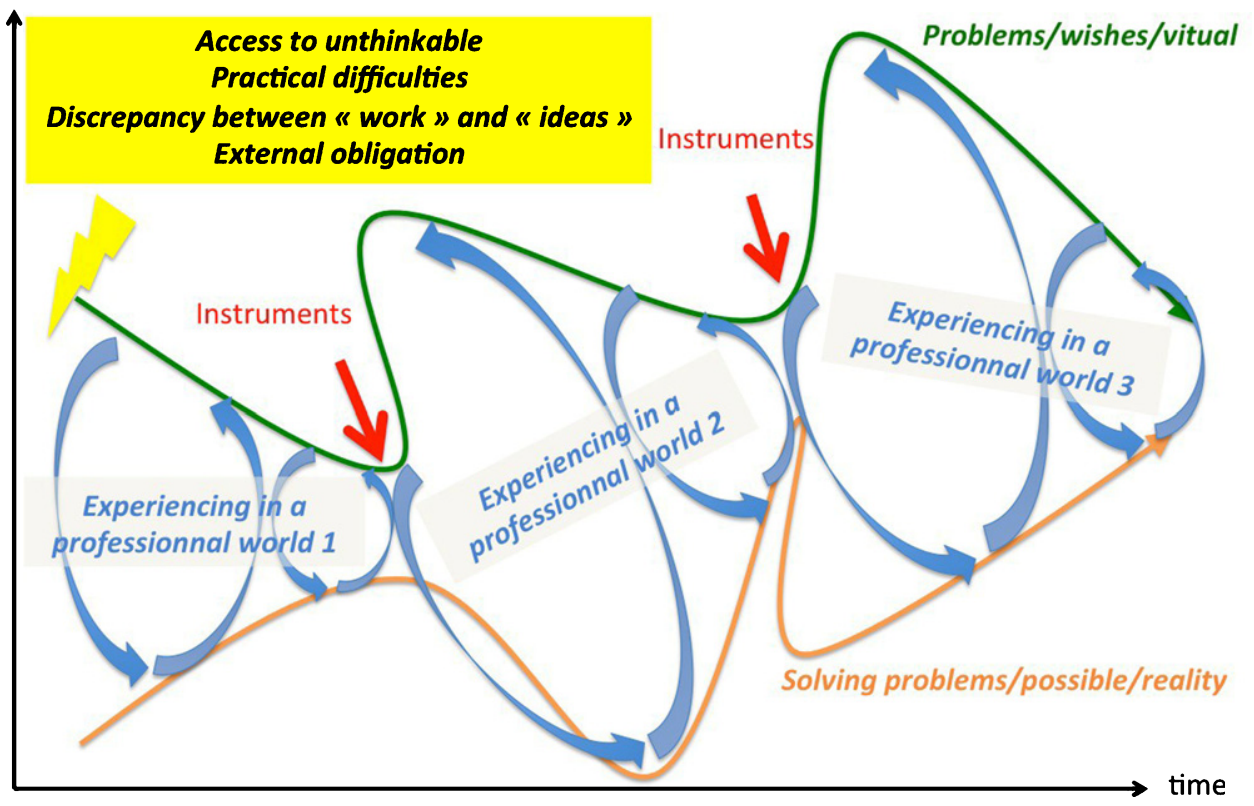

Fig. 1. Professional transition: A development of farmers' professional world.

with reality (Fig. 1). This transition process thus corresponds to Schön's "dialogue with the situation". The instruments mobilized by the farmers during the transition play two roles: they are resources mobilized by them to resolve a problematic situation; and they are drivers of change in the farmers' ways of doing and thinking, opening new perspectives in their activity. It is impossible, a priori, to grasp the magnitude of the transformations brought on by the mobilization of an instrument. The key instruments mobilized by the farmers are particularly important during their professional transition since they lead to changes in their ways of doing and thinking: their knowledge, concepts and professional norms are shifted. For example, in the case of the Maine et Loire farmer, the discovery of self-sufficient farming rationales based on grass grazing made him want to plant only grass on his farm, to be self-sufficient and autonomous. However, the health problems that soon arose in his herd and the discovery of a method to link the observation of the animals and their health with dietary recommendations led him to reconsider their diet. He subsequently kept crops such as fodder maize and certain cereals and legumes on his farm to integrate them into his cows' diet.

In addition to objects, concepts and professional norms, this example shows that instruments also sometimes lead farmers to reconsider their ambitions for the future. This development is therefore nonteleological, as the farmers' aims are not defined from the outset: they evolve over the course of the development process (see Fig. 1).

Farmers' professional transition towards selfsufficient and autonomous mixed farming is a non-incremental development in their activity. It is non-incremental in the sense that the knowledge, know-how and objects mobilized by farmers in an autonomous position lead them to relinquish part of the knowledge, know-how and work objects they mobilized in the past. Still looking at the Maine et Loire farmer, new ways of doing things appeared during the transition, such as distributing balanced meals twice a day. The composition of these meals was adjusted to preserve the animals' health, according to the state of health he observed. These observations and the link made between them and the adjustment of the meals' composition made irrelevant the indicators he had previously used during the intensive and non-autonomous period to balance his cows' rations; in other words, the balance between fodder units and digestible proteins in the intestine, determined by agronomic research.

We describe professional worlds' development processes as social and autonomous. The development processes at play in the shift in a farmer's experience during this transition towards autonomous 
mixed farming are initiated and driven partly by socio-professional dynamics surrounding the farmer, and partly by the necessary pragmatic coherence of their professional world for them to be able to act effectively.

\subsubsection{Socio-professional dynamics}

The socio-professional dynamics contributing to the development of farmers' activity manifest themselves through the discovery of the unthinkable and instrumental geneses.

- The discovery of the unthinkable and awareness of the discrepancy between "doing" and "thinking" are often triggered by encounters with individuals whose professional norms, ways of doing things or objects are at odds with those of the farmer's professional world. The possibility of living without using one's full entitlement quota was one of the discoveries made by the Maine et Loire farmer, who acted on his "autonomy" and his herd's dietary "balance".

- Artifacts convey the professional norms that a farmer actually compares to his/her reality. He/she experiments with artifacts and the reconfigurations of his/her work situation that they generate. The farmer then adheres to, rejects or qualifies the professional norms conveyed by these artifacts, based on the results of their instrumentalization in his/her work situation. When he discovered the possibility of living without using his full entitlement quota, the Maine et Loire farmer gradually transformed his ways of doing and thinking about his work through the use of instruments. The first instruments stemmed from the use of the "rotational grazing" method, which allows for normative grazing management according to markers, based on the state of the grass. When he discovered rotational grazing, the farmer wanted to turn to a $100 \%$ grass system to feed his cows, like the farmers with whom he discussed grazing management. However, the appearance of health issues in his herd prompted him gradually to study the links between diet and animal health, using another instrument to structure the development of his professional world based on the Obsalim ${ }^{\circledR}$ method. This method helps farmers to develop a diagnosis of their herds' health, and allows them to list pathways of progress in their herd's diet to resolve the animals' potential health issues. This farmer considered this method for his situation and retained two important instruments: observation of his herd, alone or with peers in the framework of practice exchange groups on his farm, in order to establish a regular diagnosis of his herd's health; and the need to develop a variety of feed (fodders, maize silage, etc.) to be able to adjust the animals' diet according to their health.

The farmer thus moved away from his desired situation and from his neighbour's professional norms, that is, exclusively feeding his animals grass. The artifacts mobilized as instruments of action by farmers therefore enable a shift, an "excentration" of farmers' activity, to use Leontiev's concept [24]. Development, as in Vygotski's [39] development model of the experiment subject, is driven by objectified knowledge and know-how in the world of goods, tools, etc.: the artifacts instrumentalized by the farmers are then mediators causing a shift in the farmer's activity and experience.

\subsubsection{Autonomous dynamics}

The dynamics within the professional world are autonomous processes contributing to its development. We formalize this conforming of the environment in situ as a farmer's implementation of a project at the service of his/her experience. The farmer's position is characterized by a dialectic: while maintaining internal coherence in his/her professional world, he/she seeks not only to: (i) resolve emerging problems by trying to provide solutions, but also to (ii) fulfill his/her wishes by matching them to the possibilities afforded by the actual situation, while (iii) maintaining the coherence needed to work efficiently.

The emergence of new problems and the shift in perspective regarding the future through access to new ways of thinking, new ways of doing things or new artifacts leads to a shift in the dialectics and to an opening of the realm of possibilities (see Fig. 1): this dialectic process between the logos (which refers to the idea) and the praxis (which refers to the action) reflects the creativity of life [40]. Putting action into effect transforms the human and artifactual facets of activity. Irrespective of the initiator of the transformation of activity, it restores the coherence of the professional world. In the collective of protagonists of the INRA ASTER-Mirecourt trial, organic specifications prohibit the use of chemical fertilizers and pesticides, and strongly minimize the use of allopathic products for animal care.

The technicians therefore had to change their practices, and worked on new objects such as the management of "fields by limiting weeds" or "the herd"s feed and fodder autonomy", which gradually led to a change in their professional norms. Following the transition to autonomous mixed farming, one of the crop group's technicians said: "we are not expecting a field with zero weeds". Another example is that 
of the two farmer brothers from the RAD in HauteNormandie: as they adhered to the professional norms of surrounding groups of autonomous farmers, they tested some of the instruments that the latter used on their farms. This testing resulted in a gradual transformation, not only of their ways of doing things, but also of the objects concerned.

The transformation can also start with a change in the farmers' value hierarchy: a farmer from the Morbihan became aware that his respect for the technical authority of the technicians intervening on his farm was the main cause of his economic difficulties: "I followed their program (pesticide treatments on cereal fields) to the letter, I had nice harvests, but when it came to selling them ... they were worth nothing..." The transformation of his professional world thus began by changing his perception of this authority, thus leaving room for his values of openness and perseverance, and allowing him to try out alternative forms of agriculture to the intensive farming he had practiced until then.

\section{Sustainable development of farming sector and professional transitions}

In this section we seek to reflect from these analyses for the support of the development of more sustainable self-sufficient and autonomous farming and for agronomic research. As we have just seen, the analysis of farmers' professional transitions sheds light on the artifacts and dynamics of change they have articulated. These artifacts can be mobilized later by other farmers interested in such transitions towards greater autonomy. Moreover, these results raise questions regarding the contribution of agronomic research, particularly concerning the design of farming systems. Thus, our purpose is to discuss how actors and research can design what Béguin et al. [41] call socio-technical systems which contribute to the development of capabilities. Such designed systems, as self-sufficient and autonomous mixed crop dairy-systems, and the process to design them can contribute to sustainable development of the sector [41]. We first discuss the method for intrinsic analysis of farmers' activity over the long term.

\subsection{Intrinsic analysis of farmers' activity over the long term}

To analyze the development of professional world over the long term, we had to reconstruct the action ex post, as it was held for the farmer, but also to formalize events and important instruments contributing to the construction of this activity in previous years. Thus, the methodological difficulty during the collection of data through interviews was double: we had to (i) prevent the events reconstructions and rationalization ex post by the interviewed farmer himself and (ii) promote a mode farmer's expression that he speaks of the activity as it unfolded and as he had experienced in its concrete work at the time it was in favor of the explanation of acts and operational divisions it had mobilized.

Following an initial open interview, we used the elicitation interview technique [38] to analyze the activity on the 2010 campaign, but also to return to events and instruments structuring development of the activity. Without claiming a formalization of the activity completely faithful to its development, elicitation interview technique is a guarantee of vigilance regarding the quality of data and loyalty to the views and life of farmers. The effort for restoring situation provides access to the action as it unfolded for the farmer.

\subsection{Conceiving of the development of sustainable agriculture based on the process of professional transition}

The formalized transition process, its factors of initiation and the resources mobilized by farmers during development offer pathways to reflect on the sustainable development of farming as regards agricultural training and support for farmers in the shift towards these forms of agriculture.

Conceiving of the unthinkable, encountering practical difficulties, awareness of the gap between "doing" and "thinking", and external constraints are the four factors of initiation of professional transition towards more self-sufficient and autonomous forms of agriculture. This transition shares the notion, with sustainable development, of proactivity of the actors involved. This proactivity involves a necessary transformation of their ways of thinking and of their professional norms in the precise case of farmers. The transformation reflects the farmers' personal value. The aim here is not to corrupt farmers but on the contrary to facilitate the emergence of new forms of farming activity by:

- Describing the diverse ways of practicing farming and of conceptually framing it, and mobilizing a wide variety of practical starting 
points to discover new ways of doing and thinking, can initiate the development process among current and future farmers. This access to alternative forms of farming is particularly important when agricultural advisors visit farmers faced with technical or economic difficulties. At that point in time, the farmer may consider these alternatives suitable.

- Access to alternative forms of farming must not be limited to their praxis: the framework of the activity must be debated and made accessible by comparing it to reality, particularly in the training of future farmers, through concrete participation in work on self-sufficient and autonomous farms. These self-sufficient and autonomous systems reflect a form of pleasure the farmers take in observing their crops and animals, and in diagnosing potential problems in these biotechnical components. This pleasure of observation must be grasped in the framework of agricultural training.

The professional transition process is nonteleological and reflects the dialectics not only between the farmer's wish for the future and what proves possible, but also between the problems that arise and the solutions that can be implemented. This process reveals the importance of integrating support for transformations in farmers' activity into a process that is personal to the farmer, and the components of which it would be interesting to identify. In other words, supporting professional transition requires a continuous characterization of the farmer's experience and of changes in its praxis and axiological dimensions. Development is embedded in this experience. The theory of professional worlds offers an interesting pathway to formalize this experience. It seems important to us to pay particular attention to the farmer's wishes regarding the future, which often reflect non-explicit desires concerning both their professional and private worlds, outside of considerations normed by the farmer's sociotechnical environment. The identification of these wishes deserves particular methodological attention.

Finally, instruments, real resources and drivers of transition towards self-sufficient and autonomous forms of farming can be resources mobilized to support farmers, as well as resources for future farmers' training. We could envisage the implementation of agricultural policies based on financial incentives to use instruments that potentially would drive the development of autonomous systems. These instru- ments imply particular ways not only of doing things but also of conceiving of farming: for example, the use of rotational grazing causes a farmer to implement grazing for his/her dairy cows, but also provides awareness of the need for adaptive rather than planned management on his/her farm. This adaptive management shifts the modalities of the farmer's learning and awakens his/her sense of observation to anticipate the necessary adjustments.

\subsection{A conception of farming systems supporting farmers' professional transitions}

We have argued that the professional transition process relates to the resolution of internal discordance within the farmer's professional world. This resolution is embedded in the farmer's experience and mobilizes social processes: confrontation with the professional norms surrounding the farmer, and the use of artifacts conveying knowledge developed by others. The proposed formalization of professional transition thus reflects two questions relating to the scientific field of design: how to embed design in users' experience and work? And, how can research contribute to this work to design more sustainable farming systems?

The vast majority of design work in the field of agronomy is invention, as understood by Staudenmaier [42]. This work focuses on the creative act, the invention of something that does not exist, keeping for a later stage the implementation of these inventions by potential users as part of their work. This research on the design of novelties leads to the production of knowledge on ways of doing things and of practicing farming, and on the performances afforded by the innovative systems invented. This knowledge is important to make potential alternatives supporting sustainable farming more appealing and credible. However it is not enough, insofar as it does not provide users with the know-how necessary for their concrete implementation. This current focus in agronomic research on the creative act is the result of a research position faithful to the Chicago Universal Exhibition: "Science Finds, Industry Applies, Man Conforms". Based on the inventions stemming from research, the only question that then remains is social acceptability. However, this position has its limits in terms of innovation, as the encounter between the object invented and the use that potential recipients can make of it is highly random and uncertain [43].

The formalization of professional transitions requires us to consider the design of innovative farm- 
ing systems in users' work, at the service of their experience. This perspective relates to innovation, in Staudenmaier's sense, that is, to understanding what things designed construct in the real world and how this modifies or reconfigures them. This perspective also relates to project management as Staudenmaier defined it, in other words, to the organization of the act of creation and production of novelty to support the evolution of users' activity and thus their experience. The production of artifacts to support farmers' professional transition towards sustainable forms of farming seems to offer an original and relevant perspective on the design of innovative farming systems. This option was chosen at the experimental facility of the INRA ASTER-Mirecourt unit: the design of innovative farming systems was carried out based on a "step-by-step" process [36], that is, the production and provision of artifacts to support change in the trial participants' ways of doing and thinking in order: (i) to overcome disorders that arise in their activity, (ii) to gain self-sufficiency and autonomy in their way of working, and (iii) to integrate key dimensions of the environmental sustainability of farming in their work. In this case, design consists of project management supporting the professional transitions of the trial participants. The operational output of this step-by-step design lies in the discussion of the instruments mobilized by the participants to develop effective ways of doing and thinking in these autonomous systems, with farmers interested in developing these forms of sustainable farming.

\section{Conclusion}

This work discussed the emergence of alternative and sustainable forms of farming in the work of farmers themselves. Addressed through the prism of the development of autonomy and self-sufficiency in farmers' professional worlds, this emergence reflects a profound transformation of their activity: their objects, concepts, knowledge and professional norms, as well as the values they embrace, change. This professional transition is initiated by the discovery of the unthinkable, a new awareness of the gap between what farmers do and what they think, the appearance of technical or financial problems in their work and, finally, the response to external constraints. Professional transition is a non-teleological process: a farmer's aim during this transition gradually evolves, leaving room for the emergence of novelties in action and the reorientation of what they desire. It is also non-incremental: some of the operative knowledge and know-how from the past are no longer part of the farmer's new professional world. This transition corresponds to a process not only of narrowing of the realm of possibilities by comparison with reality, but also of resolution of difficulties encountered by the farmers in their work. It is resolved and stimulated by the use of artifacts, instrumented by the farmers. This formalization of the initiators and processes of professional transitions towards sustainable forms of agriculture opens new perspectives not only for $(i)$ supporting the sustainable development of farming, but also for (ii) designing sustainable farming systems. The support and design of sustainable farming systems must be embedded in the farmers' activity and experience, taking into account their history, their culture and the evolution of their desires. The production and availability of artifacts allowing for the transformation of the farmer's ways of doing things and of thinking is particularly valuable for the facilitation of these transitions.

\section{Conflict of interest}

\section{None to report.}

\section{References}

[1] Antrop M. Why landscapes of the past are important for the future? Landscape and Urban Planning 2005;70(1):21-34.

[2] Chatellier V, Guyomard H. Le bilan de santé de la PAC, le découplage et l'élevage en zones difficiles. INRA, 2008.

[3] Chatellier V, Guyomard H, Perrot C, Carlier M, editors. La PAC post 2015: Vers un rééquilibrage des aides directes en faveur des ruminants? 20ème Rencontres Recherche Ruminants, 2013, Paris, France.

[4] Mignolet C, Schott C, Benoît M, Meynard JM. Transformations des systèmes de production et des systèmes de culture du bassin de la Seine depuis les années 1970: Une spécialisation des territoires aux conséquences environnementales majeures. Innovations Agronomiques 2012;22:1-16.

[5] Hostiou N, Fagon J. Simplification des conduites d'élevage: Analyse transversale des pratiques mises en oeuvre dans les filières herbivores et granivores. INRA Prod Anim 2012;25(2):127-40.

[6] Coquil X, Béguin P, Dedieu B. Systèmes de polyculture élevage laitiers évoluant vers l'AB: Renforcement des interfaces cultures/élevage. Economie Rurale. 2014; 339340:81-94.

[7] Alard V, Béranger C, Journet M. A la recherche d'une agriculture durable: Etude des systèmes herbagers économes en Bretagne. INRA ed. editions I, editor. Paris 2002, 346.

[8] Deléage E. Paysans de la parcelle á la planète: Socioanthropologie du réseau agriculture durable: Syllepse; 2004, 245. 
[9] Garambois N. Des prairies et des hommes. Les systèmes herbagers économes du Bocage poitevin: Agro-écologie, création de richesse et emploi en élevage bovin. Paris: ABIES-AgroParisTech, 2011.

[10] Gibon A, Ryschawy J, Schaller N, Blouet A, Coquil X, Martin P, Fiorelli JL, Havet A, Martel G, editors. L'élevage, un atout pour le développment durable des territoires dans les régions de polyculture-élevage. Rencontres Recherches Ruminants, 2011, Paris.

[11] Hendrickson JR, Liebig MA, Sassenrath GF. Environment and integrated agricultural systems. Renewable Agriculture and Food Systems 2008;23(4):304-13.

[12] Russelle MP, Entz MH, Franzluebbers AJ, editors. Reconsidering integrated crop- livestock systems in North America. Integrated Crop-Livestock Systems for Profit and Sustainability Papers from the ASA annual meeting, Salt Lake City, Utah, USA, 8 November 2005, 2007.

[13] Wilkins RJ. Eco-efficient approaches to land management: A case for increased integration of crop and animal production systems. Philosophical Transactions of the Royal Society B-Biological Sciences 2008;3673:517-25.

[14] Castoriadis C. L'institution imaginaire de la société: Seuil, 1975.

[15] Coquil X, Lusson JM, Beguin P, Dedieu B, editors. Itinéraires vers des systèmes autonomes et économes en intrants: Motivations, transition, apprentissages. 20eme Rencontres Recherches Ruminants; 2013, Paris, France.

[16] Hellec F, Blouet A. L'essor de l'agriculture biologique en Alsace bossue. In: van Dam D, Streith M, Nizet J, editors. Le bio en devenir Le cas alsacien. Ecopolis. Bruxelles: Peter Lang, 2011.

[17] Lusson JM, Coquil X, Falaise D, Frappat B. 40 itinéraires vers des systèmes herbagers: Comprendre les transitions pour mieux les accompagner. Fourrages 2014;2019:213-20.

[18] Geels FW, Schot J. Typology of sociotechnical transition pathways. Res Policy 2007;36(3):399-417.

[19] Chantre E. Apprentissages des agriculteurs vers la réduction d'intrants en grandes cultures: Cas de la Champagne Berrichonne de l'Indre dans les années 1985-2010: AgroParisTech, ABIES, 2011.

[20] Lamine C, Meynard JM, Perrot N, Bellon S. Analyse des formes de transition vers des agricultures plus écologiques: Les cas de l'Agriculture Biologique et de la Protection Intégrée. Innovations Agronomiques 2009;4:483-93.

[21] Rabardel P, Béguin P. Instrument Mediated Activity: From Subject Development to Anthropocentric Design. Theorical Issues in Ergonomics Science 2005;6(5):429-61.

[22] Béguin P. Monde, version des mondes et monde commun. Bulletin de Psychologie 2004;469(57):45-8.

[23] Bucciarelli L. Designing Engineers. Cambridge: MIT Press, 1994.

[24] Leontiev A. Le dévelopement du psychisme. Paris: Sociales, 1976, 343.

[25] Kaptelinin V. The object of activity: Making sense of the sense-maker. Mind Culture and Activity 2005;12(1):4-18.

[26] Béguin P. Acerca de la evolution des concepto de activitad. Labor(eal) 2006;2(1):55-61.
[27] Béguin P, Rabardel P. Designing for instrument mediated activity. Scandinavian Journal of information Systems 2000;12:173-90.

[28] Pastré P. Didactique professionnelle et conceptualisation dans l'action. In: Barbier J, Bourgeois E, Chapelle G, Ruano-orba J, editors. Encyclopédie de la formation: PUF, 2009, 1236.

[29] Lemery B. Les agriculteurs: Une profession en travail. In: Béguin P, Dedieu B, Sabourin E, editors. Le travail en agriculture: Son organisation et ses valeurs face á l'innovation. Paris: L'Harmattan; 2011, pp. 243-54.

[30] Nicourt C, editor Distinguer les "bons éleveurs". Journées INRA-SFER de recherches en sciences sociales; 20072007 12-13 - 2007-12-14; Paris, France: SFER.

[31] Nicourt C. Le Cochon d'Or. Un modèle d'excellence professionnelle pour l'élevage des porcs ? Economie Rurale 2009;313-314:24-37.

[32] Nicourt C, Cabaret J. Création de normes, innovation sanitaire et éthique des éleveurs ovin bio. In: Béguin P, Dedieu B, Sabourin E, editors. Le travail en agriculture: Son organisation et ses valeurs face á l'innovation. Paris: L'Harmattan, 2011, pp. 85-98.

[33] Dalmas M. Les valeurs: Un concept individuel et organisationnel. CEREM: Ecole de Management Léonard de Vinci, 2011.

[34] Dewey J. Theory of valuation. Universal library. 2. Chicago: The University of Chicago Press, 1939, pp. 1-67.

[35] David A. Etudes de cas et généralisation scientifique en sciences de gestion. Revue Sciences de Gestion, 2003, 39.

[36] Coquil X, Fiorelli JL, Blouet A, Mignolet C. Experiencing Organic Mixed Crop Dairy Systems: A Step-by-Step Design Centred on a Long-term Experiment. In: Springer, editor. Organic farming, prototype for sustainable agricultures, 2014, pp. 201-17.

[37] Kaufmann J. L'entretien compréhensif: Nathan, 2003. 127.

[38] Vermersch P. L'entretien d'explicitation. ESF ed. Issy-lesMoulineaux: ESF, 2010;2010:220.

[39] Vygotski LS. La méthode instrumentale en psychologie. In: Schneuwly B, Bronckart JP, editors. Vygotski aujourd'hui. Paris: Delachaux et Niestlé; 1930/1985.

[40] Joas H. La créativité de l'agir. les éditions du Cerf, Paris. 1999:306.

[41] Béguin P, Duarte F, Lima F, Pueyo V. Activity at work, innovation and sustainable development. Work 2012:41:8994.

[42] Staudenmaier JM. Technology's Storytellers. Cambridge, Massachusets: MIT Press, 1985. p. 282.

[43] Temple L, Bakry F, Marie P. Innovations sociales pour éliminer les pesticides dans les bananeraies: Les conditions de mobilisation du travail. In: Beguin P, Dedieu B, Sabourin $\mathrm{E}$, editors. Le travail en agriculture: Son organisation et ses valeurs face á l'innovation. Paris (France): L'Harmattan, 2011, pp. 115-34. 